\title{
A comparative method for protein extraction and proteome analysis by two-dimensional gel electrophoresis from banana fruit
}

\author{
Giridara-Kumar Surabhi*, Silpa Pattanaik, Subhankar Mohanty \\ Department of Forest \& Environment, Regional Plant Resource Centre, Bhubaneswar, Odisha, India
}

\author{
Received: 09-05-2016 \\ Accepted: $12-07-2016$ \\ Published: 07-08-2016 \\ *Address for \\ correspondence: \\ Dr. Giridara-Kumar Surabhi, \\ Plant Molecular Biology \\ and Genomics Laboratory, \\ Seed Bank and Seed \\ Biology Division, Regional \\ Plant Resource Centre, \\ Forest \& Environment \\ Department, Government \\ of Odisha, Nayapalli, \\ Bhubaneswar - 751015 , \\ Odisha, India \\ E-mail: surabhigk@gmail. \\ com
}

\begin{abstract}
Bananas and plantains are a major staple food and export product in many countries. Banana fruit tissues contain large amounts of secondary compounds, polysaccharides, and other plant polymers, which will interfere with protein extraction for gel-based proteomic analysis. Due to the presence of a very small amount of proteins (approximately 1\%) in a large matrix of fruit tissues, it classified as "recalcitrant." In this connection, assessment of different protein extraction protocols and extraction of high-quality proteins from banana fruit tissues is crucial for successful gel-based proteome analysis. In this study, two different protein extraction protocols were validated to isolate proteins from banana (cv.Grand Naine) fruit peel and pulp tissues, and proteins were resolved using sodium dodecyl sulfate-polyacrylamide gel electrophoresis. A comparative study showed that phenol-based method is effective in extracting proteins over trichloroacetic acid-acetone method. Isolated proteins were further subjected to two-dimensional (2D) gel electrophoresis separation and stained with colloidal Coomassie blue to visualize protein spots. On average 380 protein spots could be detected on Coomassie-stained 2D gel, and our study clearly demonstrated the differential protein accumulation during pre-climacteric and climacteric stages of banana fruit.
\end{abstract}

KEY WORDS: Banana, phenol, ripening, trichloroacetic acid-acetone, two-dimensional gel electrophoresis

\section{INTRODUCTION}

Bananas and plantains are major fruit crops in many countries. India stands as the largest producer of banana with an annual production of 28.4 million tons on 796,500 ha, which contribute to $27 \%$ of the world production and about $38 \%$ of the total fruit crop production in the nation (FAOSTAT, 2011). In developing countries, post-harvest losses of fruits and vegetables account for almost $50 \%$ of the produce. India, the world's second largest producer of fruits and vegetables, loses $35-40 \%$ of the produce due to excessive softening. Excessive softening exacerbates the damage incurred during handling, decreases the shelf life of fruits, and increases the susceptibility toward postharvest pathogens. Fruit ripening is a highly coordinated, genetically programmed, irreversible phenomenon that involves a complex series of physiological and biochemical events. However, proteomic investigations on banana fruits during development and ripening are still limited.
Current proteomic methods can be divided into two groups: gel-based approaches, including conventional two-dimensional gel electrophoresis (2-DE) and differential in-gel electrophoresis, and gel-free mass spectrometry-based approaches. Despite rapid advances in gel-free proteomics, 2-DE coupled with mass spectrometry is still the primary platform for proteomic analysis (Cottrell et al., 2011). Previously, some proteome reports have appeared on different tissues of banana such as meristem (Carpentier et al., 2007; Samyn et al., 2007), leaf (Vertommen et al., 2011; Lu et al., 2013), and root (Vaganan et al., 2015) tissues. DominguezPuigjaner et al. (1992) studied banana fruit proteins from four different ripening stages. In their study, separation was limited to the 2-DE (non-equilibrium $\mathrm{pH}$ gel electrophoresis/sodium dodecyl sulfate-polyacrylamide gel electrophoresis [SDS-PAGE]), and they could visualize a very few protein spots (as low as $30-40$ spots) on a typical Coomassie blue stained 2D gel, with the protein 
extraction method which they followed. Although some recent studies were conducted for banana fruit proteome using both conventional protein extraction (Toledo et al., 2012) and newly developed combinatorial peptide ligand libraries (CPLL) method (Esteve et al., 2013; Righetti et al., 2015), the development of efficient protein extraction protocols for gel-based proteomic analysis is still for from the fruition. Further, proteins extracted through the CPLL method from banana fruit has restricted to one-dimensional SDS-PAGE separation (Esteve et al., 2013; Righetti et al., 2015).

A protocol found suitable for a particular plant of a species might not be appropriate for the other. It is improbable to define a single protein extraction protocol for different tissues that are endowed with developmental-specific metabolites, and similar views were proposed in earlier studies (Stalikas, 2007; Wu et al., 2014). Every protein extraction method and subsequent analytical procedure have their physic-chemical limitations; both should be investigated before selecting an appropriate protocol for conducting in-depth proteome studies.

To date, no in-depth work has focused on identifying the banana fruit proteome using 2D gel-electrophoresis. The banana pulp contains approximately $20 \%$ carbohydrates and only $1 \%$ proteins. This fruit has been traditionally considered as a difficult matrix for protein extraction, being a target in studies of optimization of protein extraction methodologies (Saravanan and Rose 2004 Righetti et al., 2015). The development of efficient protein extraction methods for various tissues of this crop is important since it provides subsistence for 400 million people worldwide, especially in developing countries (Carpentier et al., 2005).

In this study, extraction of proteins performed by adapting two different protocols from banana fruit and resolved using SDS-PAGE and 2-DE. The main objective of this study is to: (i) Evaluate different protein extraction methods for banana fruit tissues (peel and pulp) and suggest best suited one for gel-based proteomic analysis and (ii) comparison of protein accumulation between pre-climacteric and climacteric stages of banana fruit by 2 -DE.

\section{MATERIALS AND METHODS}

\section{Banana Fruit Sampling}

Fully developed mature banana (Musa acuminata; cv. Grand Naine) was harvested at the pre-climacteric stage, approximately 80-days after flowering from banana germplasm unit at Regional Plant Resource Centre, Bhubaneswar, Odisha, India and allowed to ripen at room temperature (RT) for 5-days. Fruit samples were selected for uniformity of size, shape, color, firmness, and visual defects. Based on physico-chemical properties, preclimacteric and climacteric stages were identified, and samples were considered for the protein extraction. The peel and pulp tissues were separated, flash frozen in liquid $\mathrm{N}_{2}$ and stored at $-80^{\circ} \mathrm{C}$ until use.

\section{Protein Extraction}

Two different protein extraction methods were followed for effective protein extraction from banana pulp and peel tissues.

\section{Trichloroacetic acid (TCA)-acetone extraction}

Protein mining was performed using a TCA-acetone precipitation, followed by a phenol extraction according to Wang et al. (2006); a separate extraction was performed for each biological replicate. Total protein content after the first precipitation step and final protein extraction yield were determined for each ripening stage (pre-climacteric and climacteric stage). Briefly, frozen fruits were finely powdered in a mortar with liquid $\mathrm{N}_{2}$ and dried under vacuum. Samples containing $1 \mathrm{~g}$ of dried tissue were suspended in $5 \mathrm{ml}$ of $10 \% \mathrm{w} / \mathrm{vTCA}$-acetone, thoroughly vortexed for $3 \mathrm{~min}$, centrifuged at $16,000 \times g$ for $3 \mathrm{~min}$, at $4^{\circ} \mathrm{C}$, and removed the supernatant.

Samples were extracted with $10 \mathrm{ml}$ of iced $80 \%$ methanol, containing $0.01 \%$ ammonium acetate, and then with $10 \mathrm{ml}$ of iced $80 \%$ acetone, in both cases following the vortexing and centrifugation steps reported above. After air drying at RT for $5 \mathrm{~min}$, samples were added with $7.5 \mathrm{ml}$ of ice-cold extraction buffer (700 mM sucrose, $500 \mathrm{mM}$ Tris- $\mathrm{HCl}$ [pH 7.5], $50 \mathrm{mM}$ ethylenediaminetetraacetic acid [EDTA], $100 \mathrm{mM} \mathrm{KCl}$, $2 \% \mathrm{w} / \mathrm{v} \beta$-mercaptoethanol, $1 \mathrm{mM}$ phenylmethylsulfonyl fluoride, $1 \% \mathrm{w} / \mathrm{v}$ polyvinylpyrrolidone, $0.25 \% \mathrm{w} / \mathrm{v}$ 3 - [(3-Cholamidopropyl) dimethylam monio]-1 propanesulfonate [CHAPS]) and then with an equal volume of phenol-saturated - $500 \mathrm{mM}$ Tris- $\mathrm{HCl}(\mathrm{pH}$ : 8.0). Samples were extracted in a Waring blender for $5 \mathrm{~min}$ and then centrifuged at $10,000 \times g$ for $15 \mathrm{~min}$, at $4^{\circ} \mathrm{C}$. Proteins were precipitated from the phenol phase by addition of 5 volume of saturated ammonium acetate in methanol, at $-20^{\circ} \mathrm{C}$, overnight; they were pelleted at $10,000 \times g$, for $15 \mathrm{~min}$, dried under vacuum, washed at first with iced $0.1 \mathrm{M}$ ammonium acetate in methanol and then twice with cold acetone. During each washing step, vortexing for $3 \mathrm{~min}$, centrifugation at $10,000 \times \mathrm{g}$, at $4^{\circ} \mathrm{C}$, and a brief air drying was performed. 


\section{Phenol extraction}

The proteins from banana pulp and peel tissues were phenol extracted according to Carpentier et al. (2005). $1 \mathrm{~g}$ of pulp and peel (separately), powdered in liquid $\mathrm{N}_{2}$, was suspended in $5.0 \mathrm{ml}$ of cold extraction buffer $(50 \mathrm{mM}$ Tris- $\mathrm{HCl}$ [pH 8.5], 5 mM EDTA, $100 \mathrm{mM} \mathrm{KCl,} \mathrm{1 \%} \mathrm{w/v}$ dithiothreitol [DTT], 30\% w/v sucrose) containing a protease inhibitor cocktail (Sigma-Aldrich P9599) and was vortexed for $30 \mathrm{~s}$. An equal volume of cold Tris-HClbuffered phenol ( $\mathrm{pH}$ 8.0) was added, and the solution was stirred for $15 \mathrm{~min}$ at $4^{\circ} \mathrm{C}$. The phenol phase was recovered by centrifugation at $6000 \times g$ for $30 \mathrm{~min}$ at $4{ }^{\circ} \mathrm{C}$ and was re-extracted with the aqueous buffer. The proteins were precipitated overnight at $-20^{\circ} \mathrm{C}$ in $100 \mathrm{mM}$ ammonium acetate/methanol and recovered by centrifugation $\left(16,000 \times g, 45 \mathrm{~min}, 4^{\circ} \mathrm{C}\right)$. The pellets were washed with $0.2 \% \mathrm{w} / \mathrm{v}$ DTT in acetone and air dried at RT.

\section{SDS-PAGE}

During SDS-PAGE analysis, protein samples $(50 \mu \mathrm{g})$ were dissolved in loading buffer containing $20 \mathrm{mM}$ DTT and ran on $12 \%$ polyacrylamide gel, which was then stained with GelCode blue stain reagent (Pierce Chemical Company).

\section{2-DE}

The proteins were solubilized in $7 \mathrm{M}$ urea, $2 \mathrm{M}$ thiourea, 4\% w/v CHAPS, 1\% w/v DTT, 0.5\% v/v immobilized $\mathrm{pH}$ gradient (IPG) buffer ( $\mathrm{pH}$ 3-10) for Coomassie staining of the gels. Proteins were quantified using the 2D-Quant Kit (GE Healthcare) and BSA as a standard as per the manufactures recommendations.

For separation on an IPGphor II unit (wipro GE Healthcare), the following parameters were used: $14 \mathrm{~h}$ rehydration, $1 \mathrm{~h}$ gradient to $250 \mathrm{~V}, 1 \mathrm{~h}$ gradient to $500 \mathrm{~V}$, $1 \mathrm{~h}$ gradient to $4000 \mathrm{~V}$, and $5.30 \mathrm{~h} 4000 \mathrm{~V}$ with a total of about $25 \mathrm{kVh}$. After isoelectric focusing (IEF), IPG strips were equilibrated for $15 \mathrm{~min}$ in buffer A $(1.5 \mathrm{M} \mathrm{mM}$ Tris- $\mathrm{HCl} \mathrm{pH} 8.8,6 \mathrm{M}$ urea, 30\% v/v glycerin, 2\% w/v SDS, 20 mM DTT, 0.01\% bromophenol blue). The strips were then placed on top of a 12\% SDS-polyacrylamide gel and covered with $0.5 \%$ agarose. Separation in the second dimension was performed using a Hoefer SE600 apparatus (wipro GE Healthcare). Afterward, gels were washed for 5 min with distilled water, and proteins were visualized with GelCode blue stain reagent following the manufacturer's instructions.

\section{Image Acquisition and Analysis}

Image acquisition was performed using Chemi-Doc (BioRad) gel documentation system using Image Lab 4.1 version software (Bio-Rad), and 2D images were analyzed using IMP 7 (version 7.1; Wipro GE Healthcare) 2D image analysis software.

\section{RESULTS}

Phenol extraction of the proteins from banana pulp and peel tissues at climacteric stage resulted in the preparation of high-quality proteins for SDS-PAGE separation. Distinct qualitative and quantitative differences were noticed in the protein separation pattern between the methods followed in the present study. The majorities of phenol extracted proteins were resolved between 30 and $100 \mathrm{kDa}$, and whereas most of these protein bands were absent in TCAacetone extracted protein samples in the same molecular weight range (Figure 1a and b).

IEF was performed with $150 \mu \mathrm{g}$ of the proteins (preclimacteric and climacteric stages) followed by 2-DE on $12 \%$ SDS-PAGE gel (Figure 2). The majority of the protein spots was distributed (using pH 3-10 IPG strips) in molecular weight/pI range from 30 to $190 \mathrm{kDa}$ and 4.0 to 8.0. Quantitative and qualitative differences were observed in the number and resolution of protein spots (Figure 3), with no visible horizontal or vertical streaking.

Separation of protein samples and comparison of 2D gels from pre-climacteric (Figure 3a-d) and climacteric (Figure 3e-h) stages were clearly demonstrated the differential expression of different sets of proteins in these two stages, due to alterations in different biochemical pathways involved in the ripening process. After subjecting 2D gel images to the software, on average 380 protein spots could be detected on a typical

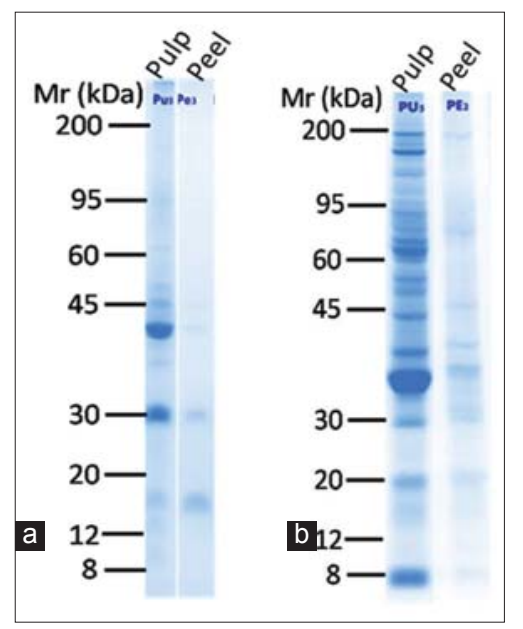

Figure 1: Sodium dodecyl sulfate-polyacrylamide gel electrophoresis profiling of protein samples extracted from banana pulp and peel tissues using trichloroacetic acid-acetone (a) and phenol extraction (b) methods, and proteins were resolved on $12 \%$ gel 


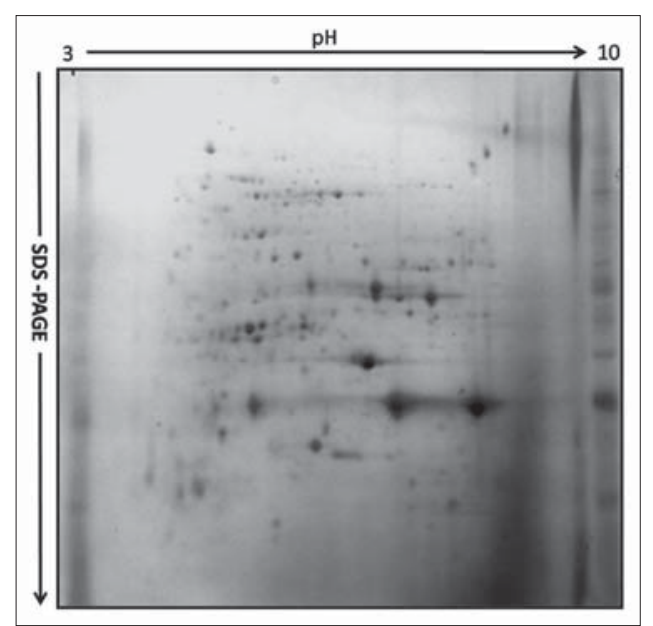

Figure 2: Two-dimensional gel of protein extracts from banana pulp tissue obtained by the phenol extraction method. $150 \mu \mathrm{g}$ proteins were separated on $13 \mathrm{~cm}$ immobilized $\mathrm{pH}$ gradient strips over a nonlinear $\mathrm{pH}$ range of 3-10 and then separated in the second dimension using $12 \%$ polyacrylamide gel. Gels was stained with GelCode blue stain reagent

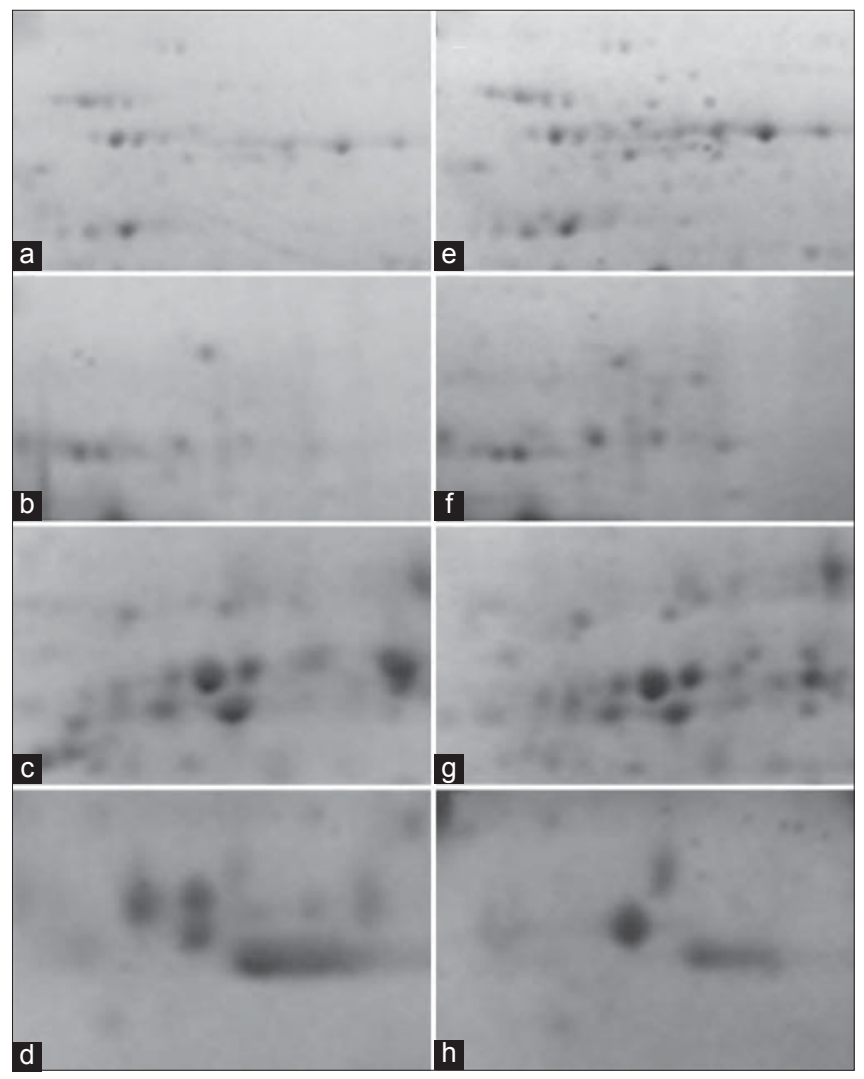

Figure 3: Portion of two-dimensional gel zoomed to visualize differentially accumulated proteins at pre-climacteric (a-d) and climacteric (e-h) stages of banana

2D gel. Images were subjected to 2D image analysis software (ImageMaster 2D platinum, vession-7.1, Wipro GE Healthcare), to identify differentially expressed protein spots.

\section{DISCUSSION}

Banana (Musa spp.) is a good representative of a difficult plant species for protein extraction since it contains many interfering metabolites. To date, only classicalTCAacetone precipitation and phenol extraction methods proved useful as standard methods for protein extraction from different plant species and organs (Sebastiana et al., 2013; Wu et al., 2014; Singh et al., 2015; Vaganan et al., 2015). Previously, variations in spot number were also noticed in different studies which used different methods of protein extraction and staining (Saravanan and Rose, 2004; Witzel et al., 2007; Singh et al., 2015). It was apparent from previous studies that a protocol for protein extraction needs to be tissue and/or species specific. However, no protocol has yet been reported for optimal extraction of high-quality proteins from different tissues of (vegetative and reproductive) banana for 2D gel-based proteomic analysis.

The TCA-acetone protocol was initially developed by Damerval et al. (1986) and is based on protein denaturation and precipitation under acidic/hydrophobic conditions, which help to concentrate proteins and remove contaminants (Wang et al., 2008). Up to date, this is the most used protocol for protein extraction from plant tissues for gel-based proteomic analysis (Jorrín et al., 2007; Jorrín-Novo et al., 2009). Although TCAacetone is a very effective protein precipitant and an instant arrestor of proteolytic activity as a strong acid, the incomplete resolubilization of the protein in TCAacetone protocol might have resulted in less number of protein bands and under representation of proteins in SDS-PAGE separation in this study, and our results are in agreement with several previous reports on different plant species and organs (Sebastiana et al., 2013; Singh et al., 2015; Vaganan et al., 2015). Overall, the general consensus is that TCA-acetone-based protein extraction is effective for younger tissues (Damerval et al., 1986; Santoni et al., 1997) and seeds (Carpentier et al., 2005; Singh et al., 2015) and may not be effective for isolation of proteins from fruit tissues.

The phenol-based method has the potential to generate samples of higher purity for recalcitrant tissues than the TCA-acetone method, as compounds such as polysaccharides and other water-soluble contaminants are separated from the proteins that are solubilized in the phenolic layer (Hurkman and Tanaka, 1986). Further, for other recalcitrant plant materials containing high level of phenols and soluble polysaccharides (as tomato 
tissues, banana and avocado mesocarp, and orange peel), the phenol method showed a high efficiency for protein extraction and resolution (Wang et al., 2003; Rose et al., 2004, Saravanan and Rose, 2004; Carpentier et al., 2005). The final pellet obtained was easily solubilized in the IEF solubilization buffer. An example of a 2-DE pattern obtained by phenol is shown in Figure 2. The quality of the spots was high in the present study; even the basic polypeptides and those in the low molecular weight region of the gel appeared as round spots, well resolved and not diffused. Moreover, the gel patterns obtained by phenol extraction had a greater number of high molecular weight proteins and our results are in consistence with the previous gel-based proteomic studies on different plant species, including fruit proteomic studies (Andrade Jde et al., 2012; Nilo et al., 2010; Singh et al., 2015; Vaganan et al., 2015). The high spot resolution, the low background, and the absence of vertical staining indicate that phenol sufficiently removed interfering compounds by partitioning them in the aqueous phase.

In the present study, around 380 protein spots could be detected on the average 2D gel with the $\mathrm{pH}$ range 3-10. Earlier similar results were obtained in different fruit proteomic studies, i.e. 373 protein spots in mango (Andrade et al., 2012), in apricot at different ripening stages on average 511,554 , and 450 spots for yellow, green, and deep-orange/red stage, respectively, using gel-based proteomic analysis (D’ Ambrosio et al., 2013). Toledo et al. (2012) conducted gel-based proteome analysis (2D fluorescence difference gel electrophoresis) for the proteins extracted from pre-climacteric and climacteric stages of ripening banana fruit and identified 168 validated spots. Investigation of the proteins that are functional during different developmental and ripening stages may provide clues for the manipulation of key metabolic pathways and the development of the desired phenotypes of important fruits in general and banana in particular.

\section{CONCLUSION}

Protein extraction using two different methods from peel and pulp tissues of banana fruit were optimized. Irrespective of the tissue (peel and pulp) used for protein extraction, protocol based on phenol extraction gave optimal yield compared with TCA-acetone method. Established high-quality protein extraction protocols in this study would be highly useful in conducting in-depth gel-based proteomic analysis in banana.

\section{ACKNOWLEDGMENT}

The authors wish to acknowledge the Science and Technology Department (No.1677/ST/ST-II(SC)-11/2016) and Forest and Environment Department, Government of Odisha, India, for the financial assistance and wish to thank Chief Executive, Regional Plant Resource Centre for facilities.

\section{REFERENCES}

D’Ambrosio C, Arena S, Rocco M, Verrillo F, Novi G, Viscosi $\mathrm{V}$, et al. Proteomic analysis of apricot fruit during ripening. J Proteomics 2013;78:39-57.

Andrade Jde M, Toledo TT, Nogueira SB, Cordenunsi BR, Lajolo FM, do Nascimento JR 2D-DIGE analysis of mango (Mangifera indica L.) fruit reveals major proteomic changes associated with ripening. J Proteomics 2012;75:3331-41.

Carpentier SC, Witters E, Laukens K, Deckers P, Swennen R, Panis B. Preparation of protein extracts from recalcitrant plant tissues: An evaluation of different methods for two-dimensional gel electrophoresis analysis. Proteomics 2005;5:2497-507.

Carpentier SC, Witters E, Laukens K, Van Onckelen H, Swennen R, Panis B. Banana (Musa spp.) as a model to study the meristem proteome: Acclimation to osmotic stress. Proteomics 2007; 7:92-105.

Cottrell JS. Protein identification using MS/MS data. J Proteomics 2011;74:1842-51.

Damerval C, De Vienne D, Zivy M, Thiellement H. Technical improvements in two-dimensional electrophoresis increase the level of genetic variation detected in wheat-seedling proteins. Electrophoresis 1986;7:52-4.

Dominguez-Puigjaner E, Vendrell M, Ludevid MD. Differential protein accumulation in banana fruit during ripening. Plant Physiol 1992;98:157-62.

Esteve C, D’Amato A, Marina ML, García MC, Righetti PG. In-depth proteomic analysis of banana (Musa spp.) fruit with combinatorial peptide ligand libraries. Electrophoresis 2013;34:207-14.

FAOSTAT. 2011. Data Base. Available from: http://www. faostat3.fao.org/.

Hurkman WJ, Tanaka CK. Solubilization of plant membrane proteins for analysis by two-dimensional gel electrophoresis. Plant Physiol 1986;81:802-6.

Jorrín JV, Maldonado AM, Castillejo MA. Plant proteome analysis: A 2006 update. Proteomics 2007;7:2947-62.

Jorrín-Novo JV, Maldonado AM, Echevarría-Zomeño S, Valledor L, Castillejo MA, Curto M, et al. Plant proteomics update (2007-2008): Second-generation proteomic techniques, an appropriate experimental design, and data analysis to fulfill MIAPE standards, increase plant proteome 
coverage and expand biological knowledge. J Proteomics 2009; 72:285-314.

Lu Y, Qi YX, Zhang H, Zhang HQ, Pu JJ, Xie YX. Separation and identification of Musa acuminate colla (banana) leaf proteins by two-dimensional gel electrophoresis and mass spectrometry. Genet Mol Res 2013;12:6871-81.

Nilo R, Saffie C, Lilley K, Baeza-Yates R, Cambiazo V, Campos-Vargas R, et al. Proteomic analysis of peach fruit mesocarp softening and chilling injury using difference gel electrophoresis (DIGE). BMC Genomics 2010;11:43.

Righetti PG, Esteve C, D’Amato A, Fasoli E, Luisa Marina M, Concepción García M. A sarabande of tropical fruit proteomics: Avocado, banana, and mango. Proteomics 2015;15:1639-45.

Rose JK, Bashir S, Giovannoni JJ, Jahn MM, Saravanan RS. Tackling the plant proteome: Practical approaches, hurdles and experimental tools. Plant J 2004;39:715-33.

Samyn B, Sergeant K, Carpentier S, Debyser G, Panis B, Swennen R, et al. Functional proteome analysis of the banana plant (Musa spp.) using de novo sequence analysis of derivatized peptides. J Proteome Res 2007;6:70-80.

Santoni V, Delarue M, Caboche M, Bellini C. A comparison of two-dimensional electrophoresis data with phenotypical traits in Arabidopsis leads to the identification of a mutant (cri1) that accumulates cytokinins. Planta 1997;202:62-9.

Saravanan RS, Rose JK. A critical evaluation of sample extraction techniques for enhanced proteomic analysis of recalcitrant plant tissues. Proteomics 2004;4:2522-32.

Sebastiana M, Figueiredo A, Monteiro F, Martins J, Franco C, Coelho AV. A possible approach for gel-based proteomic studies in recalcitrant woody plants. Springerplus 2013;2:210.

Singh N, Jain N, Kumar R, Jain A, Singh NK, RaiV. A comparative method for protein extraction and 2-D gel electrophoresis from different tissues of Cajanus cajan. Front Plant Sci $2015 ; 6: 606$.
Stalikas CD. Extraction, separation, and detection methods for phenolic acids and flavonoids. J Sep Sci 2007;30:3268-95.

Toledo TT, Nogueira SB, Cordenunsi BR, Gozzo FC, Pilau EJ, Lajolo FM, et al. Proteomic analysis of banana fruit reveals proteins that are differentially accumulated during ripening. Postharvest Biol Tec 2012;70:51-8.

Vaganan MM, Sarumathi S, Nandakumar A, Ravi I, Mustaffa MM. Evaluation of different protein extraction methods for banana (Musa spp.) root proteome analysis by twodimensional electrophoresis. Indian J Biochem Biophys 2015;52:101-6.

Vertommen A, Møller AL, Cordewener JH, Swennen R, Panis B, Finnie C, et al. A workflow for peptide-based proteomics in a poorly sequenced plant: A case study on the plasma membrane proteome of banana. J Proteomics 2011;74:1218-29.

Wang W, Tai F, Chen S. Optimizing protein extraction from plant tissues for enhanced proteomics analysis. J Sep Sci 2008;31:2032-9.

Wang W, Vignani R, Scali M, Cresti M. A universal and rapid protocol for protein extraction from recalcitrant plant tissues for proteomic analysis. Electrophoresis 2006;27:2782-6.

Wang W, Scali M, Vignani R, Spadafora A, Sensi E, Mazzuca $S$, et al. Protein extraction for two-dimensional electrophoresis from olive leaf, a plant tissue containing high levels of interfering compounds. Electrophoresis 2003;24:2369-75.

Witzel K, Surabhi GK, Jyothsnakumari G, Sudhakar C, Matros A, Mock HP. Quantitative proteome analysis of barley seeds using ruthenium(II)-tris-(bathophenanthrolinedisulphonate) staining. J Proteome Res 2007;6:1325-33.

Wu X, Xiong E, Wang W, Scali M, Cresti M. Universal sample preparation method integrating trichloroacetic acid/ acetone precipitation with phenol extraction for crop proteomic analysis. Nat Protoc 2014;9:362-74. 